\title{
Brechas de rentabilidad económica en pequeñas unidades de producción de leche en el altiplano central mexicano
}

\author{
Gaps in economic profitability among small-scale dairy \\ farms in the Mexican Highland Plateau
}

\begin{abstract}
Carlos Eduardo Romo Baccoa, Arturo Gerardo Valdivia Floresa, Rodrigo Gabriel Carranza Trinidadb, Julio Cámara Córdovac, Martha Patricia Zavala Ariasa, Ernesto Flores Anciraa, José Antonio Espinosa Garcíad
\end{abstract}

\begin{abstract}
RESUMEN
Entre las grandes y pequeñas unidades de producción lechera (PUPL) existen brechas en la rentabilidad económica (RE) debido a economías de escala significativas; aunque también pueden hallarse al interior del estrato de pequeña escala, dificultando el avance tecnológico y sustentabilidad de la producción lechera. El objetivo fue identificar la presencia de brechas de RE y relacionarlas con los factores productivos de PUPL. Se entrevistaron 89 propietarios de PUPL del Altiplano Central Mexicano (Valle de Aguascalientes) registrados en el Programa de Capacitación y Asistencia Técnica de SAGARPA (2011; muestra con $95 \%$ de confiabilidad y 10\% de precisión; 162 variables; PUPL con <50 vacas <10 personas ocupadas, PO). Se calculó anualizada la relación beneficio costo neto (BCN), valor agregado (VA) y factores que influyeron en la existencia de BCN>1.0. Sólo una de cinco PUPL tuvo resultados superavitarios $(17 / 89=19.1 \%$; IC95\%: 14.9, $23.3 \%)$, asociados directamente $(P<0.05)$ con mayor ingreso total, VA, PO, familiares con salario, vacas atendidas/ PO, precio de venta y costo de alimentación; e inversamente con menor costo de insumos, proporción de autoconsumo familiar y valor de activos y ganado. La mano de obra familiar (2.2 PO/PUPL) predominó (85.4 \%) pero no influyó significativamente en $\mathrm{BCN}(P=0.787)$. Los ganaderos que estuvieron organizados tuvieron mejores resultados $(P<0.05)$ que aquellos que permanecieron aislados (BCN>1.0: 7/20 vs 10/69). Estos resultados sugieren que las políticas públicas y privadas pudieran enfocar sus esfuerzos a cerrar las brechas de RE entre PUPL, mejorando el alcance del potencial técnico de producción, las estrategias de intercambio comercial, la preservación del empleo y recursos naturales.
\end{abstract}

PALABRAS ClAVE: Sostenibilidad, Competitividad, Productividad, Eficiencia, Punto de equilibrio económico.

\begin{abstract}
Between large and small-scale dairy farms (SSDF) there are gaps in economic profitability (EP) due to significant scale economies, but also can be found within the small-scale stratum, hindering the technological advancement and milk production sustainability. The aim was to identify the presence of EP gaps and relate them to productive factors in SSDF. Eighty nine owners were interviewed (2011) in SSDF located in the Mexican Highland Plateau (Valley of Aguascalientes), recorded in the SAGARPA Program for Technical Training and Assistance (sample: 95\% confidence and $10 \%$ accuracy; SSDF with $<50$ cows and $<10$ employed persons, E; 162 variables). The net cost-benefit ratio (NCB), value-added (VA) and factors that influenced the existence of surplus (NCB >1.0) were calculated on annual basis. Only one of five SSDF had surplus results $(17 / 89=19.1 \%$; $C I 95 \%$ : 14.9, $23.3 \%$, directly associated $(P<0.05)$ with higher total income, VA, E, salaries for family members, cows by E, sales prices and feed cost; and inversely with lower cost of inputs, proportion of milk for family use and total value of assets and livestock. Other variables were not significant or correlated and were considered collinear. The family labor (2.2 E/SSDF) predominated (85.4 \%) but did not significantly influence the NCB $(P=0.787)$. In addition, farmers who were organized had better outcomes $(P<0.05)$ than those who remained isolated (NCB>1.0: 7/20 vs 10/69). These results suggest that public and private policies could focus their efforts to bridging the PE gaps between SSDF, improving the reach of technical potential for milk production, trading strategies, employment, and natural resources preservation.
\end{abstract}

KEY WORDS: Sustainability, Competitiveness, Productivity, Efficiency, Economic break-even point.

Recibido el 30 de julio de 2013. Aceptado el 30 de septiembre de 2013.

a Universidad Autónoma de Aguascalientes. Centro de Ciencias Agropecuarias. Av. Universidad 940, 20131, Aguascalientes, México. Teléfono (449) 910-74-00, Ext. 8101,8105 y 8121 . avaldiv@correo.uaa.mx. Correspondencia al segundo autor.

b Instituto Nacional de Estadística y Geografía. México.

c Universidad Juárez Autónoma de Tabasco. División Académica de Ciencias Agropecuarias. México.

d Instituto Nacional de Investigaciones Forestales y Agropecuarias. Centro Nacional de Investigación Disciplinaria en Fisiología y Mejoramiento Animal. México. 


\section{INTRODUCCIÓN}

En diversos lugares del mundo se ha propuesto que entre las grandes y pequeñas unidades de producción lechera (UPL) existen brechas de productividad, entendidas como las diferencias profundas entre la producción promedio obtenida de leche por vaca en el hato, por hectárea de terreno laborable, por jornal laborado o por año, etc.(1-4) Igualmente en México, los datos de los dos últimos censos ganaderos nacionales $(1991,2007)$ indican que la productividad de leche se ha incrementado en promedio en 14.5 millones de litros anuales por UPL mayor a 250 vacas en ordeño, mientras que en las menores de 50 vacas (PUPL), el crecimiento ha sido prácticamente marginal (0.05 ML/año)(5-6). Estas brechas de productividad se reflejan en brechas de rentabilidad económica (RE) o márgenes de ganancia promedio, atribuibles a la existencia de economías de escala significativas, donde las UPL con hatos grandes disminuyen sus gastos de operación unitarios al distribuir los costos fijos de instalaciones, equipo de ordeño y servicios de asistencia técnica, en un volumen de producción muy grande, lo cual incrementa sus ganancias y las posibilidades económicas de implementar mejoras en la calidad genética del ganado, calidad nutricional de los ingredientes alimenticios y otros elementos tecnológicos empleados(4). Sin embargo, también al interior del estrato de pequeña escala pueden existir brechas en el alcance del potencial técnico de producción y por lo tanto, en la RE y las oportunidades de avance tecnológico y sustentabilidad de la producción lechera.

La RE es un indicador que cuantifica de manera contable las relaciones de intercambio de las UPL con el mercado, por lo que refleja el equilibrio entre el costo de la mano de obra y los insumos, con el precio de los productos pagados al participante en la cadena de producción lechera $(7,8)$. También, la RE es sensible a la disponibilidad de recursos agroecológicos, distorsiones del mercado por

\section{INTRODUCTION}

Productivity gaps between large and small dairy production units exist worldwide. In this context, a productivity gap is understood as deep differences between average production per cow in a herd, per hectare of productive land, per work-day, year etc.(1-4). This scenario clearly exists in Mexico. In the previous two national livestock censuses $(1991,2007)$, milk production increased an average of 14.5 million liters annually in dairy production units larger than 250 milking cows, whereas growth was marginal in small-scale daily farm (SSDF) with less than 50 cows $(0.05 \mathrm{ML} / \mathrm{yr} / \mathrm{SSDF})(5-6)$. Productivity gaps are reflected in gaps in economic profitability (EP) or average profit margins. These can be attributed to significant economies of scale in which large dairy farms reduce their unit operating costs by distributing the fixed costs of installations, milking equipment and technical assistance services in a very large production volume, thus raising profits and the economic possibilities of improving herd genetic quality, feed ingredient nutritional quality and other technological elements(4). In addition, gaps can exist among SSDF in terms of the reach of production technical potential, opportunities for technological advancement and milk production sustainability. These can lead to gaps in EP.

As an indicator, EP quantifies the exchange relationships between the dairy farms and the market; in other words, it reflects the balance between labor and input costs, and the product price paid to milk production chain participants $(7,8)$. This indicator is also sensitive to agroecological resource availability, market distortion from subsidies, hoarding, national price controls, and international prices for milk products, inputs and milk substitutes(9-12). Economic profitability is therefore best evaluated by calculating the quantity of internal factors, including those not actually spent or received, using a net cost-benefit ratio $(\mathrm{NCB})(13,14)$ and total value-added (VA) by employed population or producing $\operatorname{cow}(7,15,16)$. In addition to being 
subsidios, acaparamiento, control nacional de precios y por los precios internacionales que alcanzan los lácteos, insumos y sustitutos de leche(9-12); por lo que es conveniente evaluar la RE calculando el monto de los factores internos, aun cuando estos no hayan sido erogados o recibidos de forma real, por medio de la relación beneficio costo neto $(B C N)(13,14)$ y el valor agregado total (VA), por población ocupada o por vaca en ordeño( $7,15,16)$. Además de asociarse a la productividad de las UPL, la RE es un indicador cuantitativo de su competitividad, entendida como una medida multidimensional del éxito para concurrir al mercado con características adecuadas de precio, calidad y disponibilidad de sus productos lácteos $(16,17)$.

En México, las PUPL constituyen la mayoría de las empresas lecheras, especialmente en las cuencas lecheras del altiplano central. En el estado de Aguascalientes (Figura 1) se tienen registradas 69,208 vacas agrupadas en 2,966 hatos, $91.2 \%$ de los que se clasifican como explotaciones familiares, en pequeña escala o de traspatio(18-20) porque cada establo ocupa a menos de 10 personas y posee menos de 50 vacas en ordeño; las vacas se mantienen en estabulación libre y producen en conjunto la quinta parte $(21.5 \%)$ del volumen total de leche en el Estado(20-21) (399 \pm 17.5 millones de litros), lo que representa $4.1 \%$ de la producción lechera nacional. Aguascalientes comparte con otros estados cercanos, como Jalisco y Guanajuato, el 29.0 \% del total de la producción nacional $(20,21)$.

El objetivo del estudio fue identificar la presencia de brechas de rentabilidad económica y relacionarlas con los factores productivos de pequeñas unidades de producción de leche en el estado de Aguascalientes, México.

\section{MATERIALES Y MÉTODOS}

Área de estudio

El estudio se realizó el Valle de Aguascalientes (Figura 1), el cual está posicionado al sur del associated with dairy farms productivity, EP is a quantitative indicator of competitiveness, understood as a multidimensional measure of success at entering the market with adequate milk product price, quality and availability $(16,17)$.

The vast majority of dairy companies in Mexico are SSDF, particularly in the dairy producing area of the Mexican Highland Plateau. The Aguascalientes State is in this geographical region. It has 69,208 registered cows grouped into 2,966 herds. Family companies account for $91.2 \%$ of this total. These are small-scale or backyard production units, meaning they are maintained by less than 10 persons, contain less than 50 dairy cows and these range freely(18-20). Though small, these SSDF account for one fifth $(21.5 \%)$ of the state's total milk volume production (399 \pm 17.5 million L), which in turn represents $4.1 \%$ of national production(20-21). Aguascalientes and the nearby states of Jalisco and Guanajuato produce $29.0 \%$ of total national milk production(20-21).

The present study objective was to identify EP gaps and relate them to production factors in small SSDF in the Aguascalientes State, Mexico.

\section{MATERIALS AND METHODS}

\section{Study area}

All studied SSDF were located in the Aguascalientes Valley (2152'50" - 22¹9'46" N; $102^{\circ} 26^{\prime} 44^{\prime \prime}-102^{\circ} 46^{\prime} 26^{\prime \prime} \mathrm{W}$ ) (Figure 1). Altitude in the area ranges from 1,800 to $2,000 \mathrm{~m}$ asl, topography is rolling hills (slope $<5.0 \%$ ), climate is semi-dry temperate with $17.4{ }^{\circ} \mathrm{C}$ average annual temperature and $526 \mathrm{~mm}$ average annual rainfall(21).

\section{Study design}

The framework of available samples was generated by grouping all SSDF employing fewer than 10 persons, with 50 or fewer dairy cows and the owners of which were registered in 2011 in the Technical Training and Assistance Program of the federal Ministry of Agriculture, 
Trópico de Cáncer, en $21^{\circ} 52^{\prime} 50^{\prime \prime}-22^{\circ} 19^{\prime} 46^{\prime \prime} \mathrm{LN}$ y $102^{\circ} 26^{\prime} 44^{\prime \prime}-102^{\circ} 46^{\prime} 26^{\prime \prime}$ LO; su altitud oscila entre 1,800 y $2,000 \mathrm{msnm}$ con pendientes suaves $(<5.0 \%)$; un clima semi-seco templado, con temperatura media anual de $17.4{ }^{\circ} \mathrm{C}$ y precipitación pluvial media de $526 \mathrm{~mm}(21)$.

\section{Diseño del muestreo}

Se obtuvo el marco de muestreo disponible agrupando las PUPL que tuvieron menos de diez personas ocupadas, no más de 50 vacas en ordeño y que sus propietarios estuvieron registrados (2011) en el Programa de Capacitación y Asistencia Técnica de la Secretaría de Agricultura, Ganadería, Desarrollo Rural, Pesca y Alimentación (SAGARPA) en el Estado de Aguascalientes o en la Asociación Ganadera Local de Productores de Leche, o bien en el registro de productores de los centros de acopio de leche (LICONSA, Granjas Fátima y Pabellón de Arteaga). Se calculó un tamaño de muestra para una población finita (sin reemplazo) para estimar la proporción de PUPL que operaban con una relación beneficio costo positiva (BCN>1.00), con $95 \%$ de confiabilidad y $10 \%$ de precisión, empleando la fórmula siguiente(22):

$$
n=\frac{N Z^{2} p q}{N d^{2}+Z^{2} p q}
$$

Donde $n$ es el tamaño de muestra seleccionado; $N$ es la población total disponible; $Z$, el valor crítico de la distribución $Z$ para el nivel de confianza 95\%; d, la precisión deseada; $p$, la proporción esperada de UPL superavitarias $(50 \%)$; y $q$, la proporción esperada de UPL deficitarias $(q=1-p)$.

Los registros se ordenaron alfabéticamente de acuerdo al primer apellido del productor y las PUPL se seleccionaron aleatoriamente de manera sistemática, calculando el producto de la fracción de muestreo correspondiente $(n=89 / N=375$ : 0.2373 ) a la cantidad de PUPL asignadas a las áreas de responsabilidad de los técnicos
Figura 1. Ubicación de las pequeñas unidades de producción de leche (cuadros; $n=89$ ) dentro del Valle de Aguascalientes (área sombreada). Fuente: Elaboración propia con datos del INEGI (2011) ${ }^{21}$

Figure 1. Location of small-scale dairy farms (squares; $n$ = 89) in Aguascalientes Valley (shaded area). Source: Developed by authors from INEGI data (2011)(21)

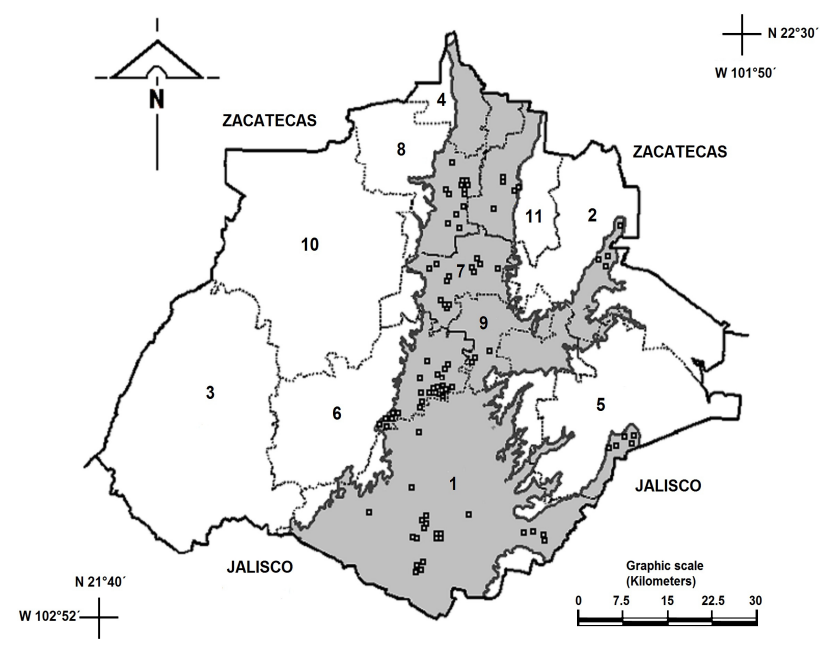

Livestock, Rural Development, Fishing and Food (Secretaría de Agricultura, Ganadería, Desarrollo Rural, Pesca y Alimentación - SAGARPA) in Aguascalientes, the Local Dairy Farmers Association (Asociación Ganadera Local de Productores de Leche) and/or the producers registered on federal milk stockpile centers (Liconsa S.A. de C.V., Fátima and Pabellón de Arteaga farms). Sample size was calculated for a finite population (without replacements) to estimate the proportion of SSDF operating with a positive net cost benefit ratio ( $\mathrm{NCB}>1.00)$ with the formula ( $95 \%$ confidence interval; $10 \%$ accuracy) (22):

$n=\frac{N Z^{2} p q}{N d^{2}+Z^{2} p q}$

where $n$ is selected sample size; $N$ is total available population; $Z$ is the critical value of the $Z$ distribution at $95 \%$ confidence; $d$ is accuracy; $p$ is the expected proportion of 
encargados de proporcionar asistencia técnica a los productores $(\mathrm{N}=12)$, para asegurar que la muestra se distribuyera homogéneamente entre este factor que pudiera influir en la rentabilidad(23).

\section{Estructura de la entrevista}

La entrevista se realizó (2011) en cuatro momentos sucesivos que incluyeron el consentimiento informado y disposición para proporcionar información confiable de las actividades, activos, ingresos y gastos, ante la declaración de confidencialidad y objetividad en el uso de la información proporcionada; exploración general de la información técnica y económica; obtención de información específica de los últimos cuatro meses anteriores a la entrevista y verificación física de recursos disponibles; así como, revisión y aceptación de los resultados por el productor.

Las PUPL se clasificaron como mano de obra tipo familiar cuando tenían al menos $50 \%$ de trabajadores que manifestaron tener un parentesco en primero o segundo grado con el o los propietarios, independientemente de que existiera o no la percepción de un salario formal. Cuando la PUPL tenía un porcentaje $<50 \%$ de mano de obra familiar se clasificó en la categoría de mano de obra contratada.

Se registraron y capturaron en una hoja de cálculo los datos de 162 variables relacionadas con la leche producida, precio de venta y otros ingresos adicionales a la venta de leche; valor de los activos, población ocupada, estructura del hato, superficie agrícola, gastos efectuados para la compra de alimentos e insumos; además de los sueldos y otros gastos e ingresos devengados mensualmente. Se incluyó información cualitativa referente a los datos socioeconómicos del propietario, del predio, prácticas tecnológicas, destino de la leche, características organizativas, entre otras.

La rentabilidad económica anualizada se estimó a partir de la relación beneficio costo neto (BCN) aplicando la fórmula siguiente(13): $B C N=$ I / (G profitable SSDF (50\%); and $q$ is the expected proportion of unprofitable SSDFs $(q=1-p)$.

Producer registries were organized alphabetically by the producer's first surname and the SSDF chosen randomly. To ensure sample homogeneity in this factor, which can affect profitability, calculations were done of the fraction of the sample corresponding $(n=89 / N=375: 0.2373)$ to the number of SSDF assigned to the areas of each technician providing technical assistance to producers $(\mathrm{N}=12)(23)$.

\section{Interview structure}

Producers were interviewed four times during 2011. After receiving the declaration of confidentiality and data use objectivity, they were asked for their informed consent. The technical and economic data they provided was evaluated and they were then asked for specific data for the four months prior to the interview. A physical evaluation of available resources was done and finally the producers were asked to review and approve the final results.

The SSDF were classified as family-run when at least $50 \%$ of workers stated they had first- or second-degree kinship to the owner(s), independent of receipt of a formal wage. When less than $50 \%$ of workers had no kinship to the owner(s) a SSDF was classified as nonfamily.

Data were collected on 162 variables including milk production variables; sale price; income in addition to milk sales; value of assets; employed population; herd structure; agricultural area; feed purchase and inputs expenses; wages; and other monthly expenses and income. Qualitative data were collected on socioeconomic factors regarding the owner; the property; technological practices; milk destination; and organizational characteristics, among others.

An estimate of EP was generated using the $\mathrm{NCB}$ ratio and the formula $(13) \mathrm{NCB}=\mathrm{I} /(\mathrm{E}+$ $\mathrm{R}+\mathrm{OC}$ ), where $\mathrm{I}=$ total income; $\mathrm{E}=$ total operational expenditures; $\mathrm{R}=$ remuneration of 
$+\mathrm{R}+\mathrm{CO}$ ), donde: $\mathrm{I}=$ total de ingresos; $\mathrm{G}=$ total de egresos operativos; $R=$ remuneraciones al personal; y $\mathrm{CO}=$ costo de oportunidad de la renta de la tierra.

El cálculo del total de ingresos (I) se realizó con la sumatoria de todas las ventas de leche reportadas por el propietario y otros ingresos adicionales. El total de egresos operativos (G) fue calculado tomando en cuenta los gastos efectuados por el propietario para llevar a cabo las operaciones productivas de la explotación, para la producción de forrajes y servicios de asistencia técnica. La remuneración al personal (R) fue calculada con la suma de todos los salarios erogados de forma real al personal ocupado y el valor de la leche destinada para el autoconsumo familiar. El costo de oportunidad de la renta de la tierra (CO) se calculó considerando como ingreso alternativo, el monto que obtendría el productor si en lugar de dedicarse a la producción lechera obtuviera el valor comercial de la renta de su propiedad(13,15), tomando en cuenta la estimación realizada por el mismo productor en base a su conocimiento de renta de predios similares en productividad y ubicación; a este monto se le agregó el valor de la mano de obra no considerada en $\mathrm{R}$; es decir, cuando no se registró un salario erogado por el trabajo realizado por el mismo productor o por algunos de sus familiares. Cuando se obtuvo una $\mathrm{BCN}>1.00$ se consideró que si obtenía utilidades y se clasificó a la PUPL como superavitaria.

Se estimó el valor agregado (VA) a partir de la diferencia entre el valor de la producción (ingresos totales obtenidos por la actividad lechera) y el consumo intermedio, representado por los gastos realizados por el productor sin considerar el costo de la mano de obra utilizada(13,15). A partir del cálculo del valor agregado total, para estimar la productividad en las PUPL, se estimó el valor agregado por población ocupada, por vaca y por activo fijo para la producción o valor total de instalaciones disponibles de manera exclusiva o compartida para la producción lechera. personnel; and $\mathrm{OC}=$ land rental opportunity cost. Total income (I) was calculated using the sum of all milk sales reported by the owner plus additional income. Total operational expenditures (E) were calculated considering owner expenses for production unit operational, forage production and technical assistance services. Remuneration of personnel ( $R$ ) was calculated using the sum of all real wages paid to working personnel and the value of the milk used for family use. Land rental opportunity cost (OC) was calculated using the amount of rent the owner would receive if he rented the property commercially instead of using it for milk production $(13,15)$; this is an alternative income that considers the owner's estimate based on knowledge of the rent paid for properties with similar productive potential and location. Labor costs not considered in $\mathrm{R}$ were then added to this value; that is, when a paid wage was not recorded for work done by the owner or his relatives. When a SSDF generated a NCB $>1.00$ it was treated as having generated a profit.

Value-added (VA) was estimated from the difference between the production value (i.e., total income from dairy production) and intermediate consumption, represented by producer expenses not including on labor costs $(13,15)$. To estimate SSDF productivity, the total VA calculation was used to estimate the VA per employed population, per cow and per fixed production assets; that is, total value of installations available for dairy production, be they exclusive or shared.

\section{Data analysis}

Collected data were analyzed with an ANOVA for 60 continuous variables (feed costs, production per cow, VA, etc.) and a KruskalWallis for 102 discrete variables (organizational structure, age in years, etc.). Significant differences were identified and statistical descriptive groups estimated using a $95 \%$ confidence interval (CI) for binomial proportions. An uncorrected Chi-squared $\left(x^{2}\right)$ was applied 
Análisis de la información

La información fue capturada y se realizó análisis de varianza para 60 variables continuas (costo de alimentación, producción por vaca, VA, etc.) y de Kruskal-Wallis para 102 variables discretas (estructura organizativa, edad en años, etc.); se corroboró la significancia de las diferencias y se estimaron los estadísticos descriptivos de los grupos, el intervalo de confianza (IC) al $95 \%$ para proporciones binomiales y se realizó la prueba de Ji-cuadrada $\left(x^{2}\right)$ no corregida, considerando como significativo un valor de $P<0.05(24)$. También se efectuó un análisis de regresión lineal múltiple, empleando el procedimiento de selección "backward" y siguiendo la fórmula siguiente: $Y_{i}=B_{0}+B_{1} z_{1}$ $+\ldots+\beta_{r} z_{r}+e_{i r i}{ }^{(24)}$ en donde las variables dependientes $\left(Y_{i}\right)$ seleccionadas $\left(Y_{1}=B C N, Y_{2}=\right.$ VA) se expresaron como una combinación lineal de la media $\left(B_{0}\right)$ y las variables independientes elegidas $\left(z_{1}=\right.$ tamaño del hato, $z_{2}=$ productividad por vaca, $Z_{3}=$ personal ocupado, $Z_{4}=$ precio de insumos, $Z_{5}=$ valor de la producción, $Z_{6}=$ tipo de organización, $Z_{7}=$ recursos agrícolas, etcétera: $Z_{r}$ ), más un término de error residual (e) que reflejó la variación no explicada por el modelo de regresión.

\section{RESULTADOS Y DISCUSIÓN}

En este estudio se observó la existencia de una brecha de RE al interior del estrato de PUPL, pues la mayoría (80.9 \%; IC 95\%: 76.7, 85.3\%) mostraron resultados económicos anualizados deficitarios $(\mathrm{BCN}<1.00)$ y no lograron pagar la totalidad de sus egresos operativos; no obtuvieron ganancias ni recursos para la reinversión o para el cuidado de sus recursos naturales. Además hubo resultados desfavorables en otros indicadores económicos (Figura 2) como el valor agregado total (\$-2,986.54), VA por población ocupada ( $\$-0.14)$, VA por vaca (\$-4,563.82) y VA por activo fijo para la producción ( $\$-0.398$ ). Sin embargo, estos propietarios manifestaron no tener presente su situación económica deficitaria, debido a que omitieron contablemente tanto el valor del with a $P<0.05$ significance level(24). A linear regression analysis was done using the "backward" selection procedure and the formula: $Y_{i}=\beta_{0}+\beta_{1} z_{1}+\ldots+\beta_{r} z_{r}+e_{i r} ;(24)$ where the selected dependent variables $\left(Y_{i} ; Y_{1}=N C B, Y_{2}=\right.$ $V A$ ) were expressed as a linear combination of the mean $\left(B_{0}\right)$ and selected independent variables $\left(Z_{1}=\right.$ herd size, $Z_{2}=$ productivity per cow, $Z_{3}=$ employed personnel, $Z_{4}=$ input cost, $Z_{5}=$ value of production, $Z_{6}=$ type of organization, $Z_{7}=$ agricultural resources, etc., $Z_{r}$ ), as well as a residual error term (e) reflecting variation unexplained by the regression model.

\section{RESULTS AND DISCUSSION}

A clear gap in EP was observed among the SSDF since most $(80.9 \% ; 95 \% \mathrm{CI}: 76.7$, $85.3 \%$ ) had a NCB <1.00, that is, their annualized economic results showed a loss. This

Figura 2. Estimación de la rentabilidad económica de pequeñas unidades de producción lechera en el estado de Aguascalientes (2011)

Figure 2. Estimated economic profitability in small-scale dairy farms (SSDF) in the Aguascalientes Valley, Aguascalientes, Mexico, in 2011

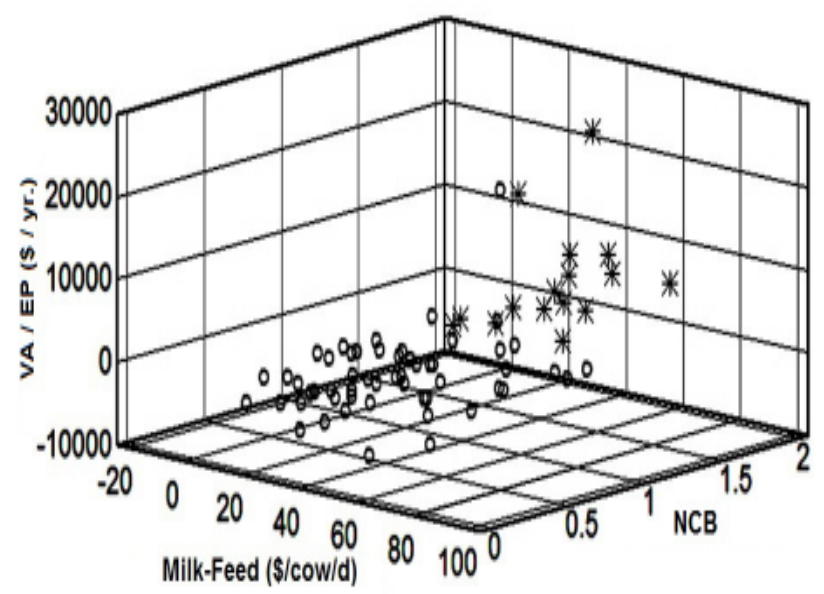

Based on profitable (asterisk) or unprofitable (circle) net costbenefit (NCB) ratio values, generation of value added per employed population (VA/EP), and ratio of value of produced milk vs cow daily feed intake (Milk-Feed). Milk-Feed values include labor and forage values not accounted for by producers. 
trabajo familiar y de los forrajes que obtienen en sus tierras, así como a la liquidez financiera continua que les proporciona la venta de productos pecuarios.

Se identificó una pequeña proporción de PUPL superavitarias $(17 / 89=19.1 \%$; IC95\%: 14.9 , $23.3 \%$ ), en las que la $\mathrm{BCN}$ fue mayor al punto de equilibrio económico $(\mathrm{BCN}>1.00)$, por lo que generaron ganancias económicas y alcanzaron a cubrir sus egresos operativos y de mantenimiento. Inesperadamente, en este estudio no se encontraron diferencias significativas $(P>0.05)$ entre la BCN de las PUPL, atribuibles a factores de indudable importancia técnica para la producción, como disponibilidad de agua de riego, tamaño de la superficie agrícola, asistencia técnica, etc. Esta falta de significancia fue atribuida por los productores a la semejanza de recursos entre las PUPL superavitarias y deficitarias, lo cual coincide con otros estudios en la región en los que sí se observan diferencias atribuibles a estos factores solamente cuando se incluyen todos los tamaños de hato diferentes $(15,25)$. Sin embargo, se observaron diferencias estadísticas significativas entre algunas variables características de las PUPL deficitarias y superavitarias, tales como la cantidad de leche producida por vaca al día, la integración del productor a una organización ganadera para la compra de insumos y venta de productos, el uso de tecnología para el ordeño, así como el control de los insumos utilizados para la alimentación del ganado (Cuadro 1).

La cantidad de experiencia acumulada entre los productores de las unidades de producción con superávit y déficit mostró diferencias significativas $(P<0.05)$, ya que los propietarios de las PUPL que obtuvieron $\mathrm{BCN}>1.00$ tuvieron en promedio $28.2 \pm 7.1$ años en la actividad lechera, mientras que los productores con déficit tenían menos experiencia (19.7 \pm 6.9$)$. En este estudio también se encontró una asociación significativa $\mathrm{x}^{2}(P<0.05)$ de la experiencia y la edad del propietario de la PUPL, reflejando que en general los productores de más experiencia tuvieron una edad mayor. occurred because they were unable to pay all operating costs, or did not generate enough profits or resources for reinvestment or to care for their natural resources. Other economic indicators were also unfavorable (Figure 2), including total VA (\$-2,986.54), VA per employed population ( $\$-0.14)$, VA per cow (\$ $-4,563.82)$, and VA per production fixed asset (\$-0.398). However, owners of unprofitable SSDF did not perceive their economic situation as a loss because they had not considered the value of their family labor, the value of the forage they obtained from their land and the continuous financial liquidity provided by sale of livestock products.

A small portion of the SSDF did generate a profit (17/89 = 19.1\%; 95\% CI: 14.9, $23.3 \%)$, with a NCB $>1.00$, above the break-even point. They generated economic profit and covered their operating and maintenance costs. Of note is that no differences $(P>0.05)$ in NCB values between different SSDF were identified that could be attributed to factors of clear technical importance for production such as irrigation water availability, agricultural surface area, technical assistance, etc. The producers attributed this lack of difference to the similarity of resources used by profitable and unprofitable SSDF. This coincides with other studies in the region in which differences were observed in these factors only when all herd sizes were included $(15,25)$. Differences were observed, however, in some characteristic variables, such as daily milk production per cow, producer membership in a livestock association for inputs purchase and product sale, milking technology and control of feed inputs (Table 1).

Between profitable and unprofitable SSDF, cumulative owner experience clearly differed $(P<0.05)$ in that the owners of SSDF with a $\mathrm{NCB}>1.00$ had an average of $28.2 \pm 7.1 \mathrm{yr}$ in dairy production whereas the owners of SSDF with NCB $<1.00$ had an average of $19.7 \pm 6.9$ $\mathrm{yr}$ in the activity. Owner age and experience were associated $(P<0.05)$, with older owners having more experience. 
Solamente el $8.3 \%$ (6/72) de las PUPL pudieran catalogarse como de subsistencia, ya que se caracterizaron por tener un autoconsumo de leche superior al $10 \%$ de la producción diaria; contaban con muy pocas vacas en producción $(2.6 \pm 1.4)$, una producción total muy baja ( $<30$ $L / d)$ y una BCN inferior a 0.35. No se identificaron diferencias estadísticas significativas en la cantidad total de leche destinada al autoconsumo (3.5 vs $5.1 \mathrm{~L} / \mathrm{d}$ ) ni en la proporción que representó en la producción (1.4 vs $3.4 \%$ ) entre las PUPL con superávit y déficit, respectivamente.

De acuerdo con algunos autores $(15,16,26)$ el grado de pérdida económica se asocia principalmente con la eficiencia productiva de la explotación. Esta afirmación significa que se acepta la posibilidad de que las pequeñas explotaciones pudieran ser tan eficientes como las grandes, y que es posible que los productores no se vean obligados a agotar sus recursos naturales, siempre que se apliquen las estrategias tecnológicas y comerciales pertinentes a las condiciones ecológicas y económicas del entorno donde realizan su
Only $8.3 \%(6 / 72)$ of the SSDF could be classified as subsistence, that is, that $>10 \%$ of daily production was for family use. These SSDF had very few cows in production (2.6 \pm 1.4 ), a very low total production ( $<30 \mathrm{~L} / \mathrm{d}$ ) and a NCB <0.35. Nonetheless, between the profitable and unprofitable SSDF, the total amount of milk production for family use (3.5 vs. $5.1 \mathrm{~L} / \mathrm{d}$ ) and the proportion this represented of total production (1.4 vs $3.4 \%$ ) did not differ.

For many authors $(15,16,26)$, degree of economic loss is mainly associated with production efficiency. This statement requires the assumption that small production units can be as profitable as large units, and that producers do not necessarily need to exhaust their natural resources as long as they apply the technological and commercial strategies most appropriate for the ecological and economic conditions where production occurs. In SSDF, variables related to technological level also influence EP generation, which in turn stimulates technological change and adoption(27-31). Finally, SSDF can be profitable if they properly manage their resources to generate valuable products $(26)$.

Cuadro 1. Factores que influyen de forma significativa $(P<0.05)$ en la rentabilidad económica de las pequeñas unidades de producción lechera

Table 1. Factors influencing $(P<0.05)$ economic profitability in small-scale dairy farms (SSDF)

\begin{tabular}{lccccc}
\hline & \multicolumn{3}{c}{ NCB ratio } & & \\
\cline { 2 - 3 } & $>1.00$ & $<1.00$ & & $\mathrm{n}$ & $P$ \\
\hline SSDF, $\mathrm{n}$ & 17 & 72 & 89 & \\
Milking cows $\mathrm{n}^{*}$ & $22.9(13.8)$ & $15.7(13.1)$ & 17.1 & 0.045 \\
Milk production, L/cow/d & $18.2(3.3)$ & $15.4(5.2)$ & 16.0 & 0.039 \\
Feed cost, $\$ /$ cow/d* & $17.6(10.9)$ & $36.3(25.8)$ & 32.7 & 0.005 \\
Milk sale price $\$ / \mathrm{L}^{*}$ & $4.4(0.5)$ & $4.1(0.5)$ & 4.1 & 0.039 \\
NCB ratio* & $1.3(0.2)$ & $0.5(0.2)$ & 0.7 & $<0.001$ \\
Organizational structure (not associated/associated) & $10 / 7$ & $59 / 13$ & $69 / 20$ & $0.040^{* *}$ \\
Milking type (non-mechanized/mechanized) & $1 / 16$ & $18 / 54$ & $19 / 70$ & $0.001^{* *}$ \\
Cooler tank (absence/presence) & $10 / 7$ & $48 / 24$ & $58 / 31$ & $0.037^{* *}$ \\
\hline
\end{tabular}

$\mathrm{NCB}=$ net cost benefit.

* Mean, standard deviation, $\mathrm{P}$ value for Fisher means test.

** Uncorrected Chi-squared with one degree of freedom. 
actividad. Se ha señalado(27-31) que las variables que tienen relación con el nivel tecnológico en las PUPL, tienen también influencia sobre la generación de ganancias económicas, lo cual a su vez estimula la adopción y cambio tecnológico, así como la RE. También este estudio se agrega a la idea de que a pesar de la escala pequeña de tamaño de la explotación, las PUPL pueden ser rentables si se establece un buen manejo de los recursos utilizados para la generación de productos de valor(26).

En el presente estudio se observaron diferencias significativas $(P<0.05)$ en la BCN relacionadas con la asociación de los productores, de tal manera que los propietarios de PUPL pertenecientes a una organización ganadera obtuvieron mayores ganancias, lo que sugiere que la asociación representa un factor de consideración para la generación de modelos aplicables a las unidades de producción. Esta afirmación concuerda con lo señalado $(32,33)$ acerca del impacto positivo de la asociación de los productores en el mejoramiento de los costos de producción, ya que las UP pueden obtener beneficios del escalamiento en la compra de insumos y para la comercialización de la leche. También se ha señalado(34) que la venta individual de la leche representa un problema en las PUPL debido a la variación de la producción durante el año y se agudiza por la falta de infraestructura de refrigeración, impactando directamente en la disminución del precio y afectando por consiguiente la RE de las PUPL.

Se ha propuesto ampliamente(10,35-37) que la edad del propietario es también un factor clave en la eficiencia de las PUPL, especialmente porque se ha observado que ocurre un ciclo de vida del ganadero, en el que los jóvenes que deciden incorporarse se dedican a perfeccionar la actividad lechera, consolidando su eficiencia en una edad media (46-64 años) mediante la adquisición y operación cuidadosa de tierras, animales, equipo y tecnología; posteriormente deciden abandonar la actividad lechera y permitir el cambio generacional. Sin embargo, de manera
In the present results, the NCB ratio was higher $(P<0.05)$ for SSDF owners belonging to a livestock association, meaning they generated greater profits than those who did not belong. This suggests that association membership is important to consider when generating production unit models. Previous studies have also stated that producer associations improve production costs since production units can benefit from economies of scale in input purchase and product sale(32,33). In addition, individual sale of milk by SSDF is problematic due to variation in production throughout the year; this is compounded by their lack of refrigeration infrastructure, which directly and negatively impacts sale price and consequently $\mathrm{EP}(34)$.

Owner age is also widely believed to be a key factor affecting SSDF efficiency(10,35-37). This is especially the case because owners enter the activity when young, learn and perfect their knowledge of dairy production, and then consolidate their efficiency in middle age (4664 yr) by acquiring and carefully operating land, animals, equipment and technology. When they retire from dairy production, the next generation, often from the same family, can progress in the activity. However, employment opportunities for young people are currently more numerous and better paid than they were for the previous generation, leading many young members of farming families to pursue other possibilities. As a result, this generational turnover is increasingly less frequent, altering succession in SSDF ownership.

Most $(85.4 \% ; 76 / 89)$ of the small SSDF (CI: $81.7,89.0 \%$ ) used family members as labor (Table 2). This coincides with the family system characterization in that most of the people employed in the SSDF have kinship ties to the owner(18-21). Although small, one out of every seven $(14.6 \%)$ of the studied SSDF had high levels of contracted labor; owners attributed this to a lack of family workers due to emigration to the United States of America. No differences $(P>0.05)$ in the proportion of profitable SSDF 
cada vez más frecuente el cambio no ocurre y se altera la continuidad de la actividad, ya que los jóvenes integrantes de las familias productoras, tienen más y mejores oportunidades de trabajo que sus padres cuando tenían su edad.

En este estudio se observó que el $85.4 \%$ (76/ 89) de las PUPL (IC: 81.7, $89.0 \%$ ) tuvieron mano de obra predominante familiar (Cuadro 2). Esta característica coincide con la tipificación del sistema familiar(18-21) al identificar que el personal ocupado mayoritario en las PUPL mantiene lazos familiares con el propietario. A pesar de su tamaño pequeño, se encontró una alta contratación de la mano de obra en una de cada siete PUPL (14.6\%), atribuida por los productores entrevistados a la baja disponibilidad de mano de obra familiar por el incremento en la migración rural hacia los EE.UU. No se encontraron diferencias significativas en la proporción de PUPL con superávit dentro de las dos categorías de empleo de mano de obra $(P>0.05)$. Lo cual pudiera significar que no es la mano de obra familiar lo que facilita o dificulta el éxito económico de las PUPL. Otras variables, como superficie de cultivo agrícola y productividad por vaca, no mostraron was observed between the two labor employment categories. This suggests that family labor may not be a variable that promotes or hinders economic success in SSDF. Other variables such as agricultural surface area and productivity per cow also exhibited no differences between family and non-family units, which agrees with previous reports $(18,29)$.

Herd size was smaller $(P<0.01)$ in the familyoperated SSDF than in those using hired labor. The proportion of family labor in the studied SSDF (2.2 persons/PU) coincided with previous reports $(14,38)$.

Negative economic results are very common among small family-run dairy companies in the Mexican Highland Plateau $(26,31,39)$. This low EP also creates challenges in caring for natural resources and adoption of new technologies, further lowering productivity and accentuating the divide between income and expenses $(8,27,40)$. It is therefore the SSDF that have the highest risk of failing $(27,41)$. A portion of the studied SSDF was near the technical production potential, emphasizing that the gap in EP can be bridged by imitating the strategies of more advanced SSDF. Milk production on the Mexican

Cuadro 2. Estructura organizacional familiar/no familiar de las pequeñas unidades de producción de leche (SSDF)

Table 2. Family/non-family structural organization of small-scale dairy farms (SSDF)

\begin{tabular}{lcccccr}
\hline & \multicolumn{4}{c}{ Organization } & \\
\cline { 2 - 5 } & \multicolumn{2}{c}{ Family } & \multicolumn{3}{c}{ Non-Family } & $P^{2}$ \\
\hline SSDF, $\mathrm{n}$ & 76 & & 13 & & \\
Contracted labor, $\mathrm{n}{ }^{1}$ & 0.1 & $(0.0,1.0)$ & 1.6 & $(1.4,1.8)$ & $<.0001$ \\
Family labor, ${ }^{1}$ & 2.2 & $(1.9,2.5)$ & 1.1 & $(0.4,1.8)$ & 0.007 \\
Total employed persons, $\mathrm{n}^{1}$ & 2.3 & $(2.0,2.6)$ & 2.7 & $(2.0,3.4)$ & 0.286 \\
Milking cows, $\mathrm{n}^{1}$ & 15.3 & $(12.5,18.1)$ & 27.5 & $(20.6,34.4)$ & 0.002 \\
Agricultural area, ha & 6.2 & $(4.7,7.7)$ & 9.1 & $(5.4,12.8)$ & 0.171 \\
Productivity per cow, L/d) 1 & 15.9 & $(14.8,17.0)$ & 16.1 & $(13.4,18.8)$ & 0.898 \\
NCB & 0.6 & $(-0.1,1.3)$ & 0.6 & $(-0.1,1.3)$ & 0.787 \\
\hline
\end{tabular}

1 Mean $(95 \% \mathrm{Cl})$.

2 Uncorrected Chi-squared with one degree of freedom.

$\mathrm{NCB}=$ net cost benefit ratio. 
diferencias significativas $(P>0.05)$ entre unidades familiares y no familiares. Lo anterior concuerda con lo señalado por diversos autores $(18,29)$.

En este estudio, el tamaño del hato fue más pequeño entre las PUPL que operaban bajo un sistema de trabajo sustentado en la mano de obra de tipo familiar, en comparación con las que empleaban mano de obra contratada $(P<0.01)$. La proporción de empleo de la mano de obra familiar en las PUPL (2.2 personas/UP) coincide con lo señalado anteriormente $(14,38)$.

Diversos autores $(26,31,39)$ han identificado que los resultados económicos negativos son muy comunes entre las pequeñas empresas lecheras familiares ubicadas en el altiplano central mexicano; así también hay coincidencia en identificar que la baja RE trae consigo dificultades para el cuidado de los recursos naturales y la adopción de innovaciones tecnológicas, lo cual redunda en una productividad baja que acentúa más la disparidad entre ingresos y egresos $(8,27,40)$, lo que significa que son precisamente los pequeños
Highland Plateau is done using different production systems, including the family system. Within this system, each production unit functions with an employed population consisting of family members, only small land areas are used, herds are $<60$ head and technology is rudimentary or artisanal $(15,40,41)$. Other classifications proposed for SSDF are subsistence, specialized and mixed. Kinship between the owner and the employed population does not distinguish any of these production systems. What does distinguish them is their technological and agroecological characteristics(26), suggesting that SSDF are not effectively differentiated by their employed population (i.e. family, nonfamily), but by other factors (see Table 1).

The linear regression analysis showed that a NCB ratio showing a surplus was directly related to maximizing income from marketing and efficient use of resources available in the SSDF, as well as variables related to minimizing production costs (Table 3 ). The regression model had an $88 \%$ efficiency for a SSDF to turn a profit $(\mathrm{NCB}>1.0)$ via a rate of coincidence

Cuadro 3. Modelo de regresión lineal empleado para estimar la relación beneficio costo neto en pequeñas unidades de producción lechera (SSDF)

Table 3. Linear regression model used to estimate net cost-benefit ratio in small-scale dairy farms (SSDF)

\begin{tabular}{llll}
\hline Variable & Coefficient & \multicolumn{1}{c}{ SEM } & $P$-value \\
\hline Constant & 0.475145 & 0.189946 & 0.0145 \\
Income from milk sales, $10^{3} \mathrm{MX} \$ / \mathrm{mo}$ & 0.00647554 & 0.00105433 & 0.0000 \\
Value added, $10^{3} \mathrm{MX} \$ / \mathrm{cow}$ & 0.147464 & 0.0238907 & 0.0000 \\
Total income, $10^{6} \mathrm{MX} \$ \mathrm{mo}$ & -5.918 & 1.13407 & 0.0000 \\
Property value, $10^{6} \mathrm{MX} \$$ & -0.0231728 & 0.00296259 & 0.0000 \\
Milk for family use, $\%$ of total production & -0.0182665 & 0.0048467 & 0.0003 \\
Wage-earning family members, $\mathrm{n}$ & 0.0930075 & 0.0263865 & 0.0007 \\
Cows worked per employee, $\mathrm{n}$ & 0.00748583 & 0.00315498 & 0.0202 \\
Additional income, $10^{3} \mathrm{MX} \$ / \mathrm{mo}$ & 0.0135814 & 0.00595274 & 0.0253 \\
Milk sale price, $\mathrm{MX} \$ / \mathrm{L}$ & 0.077531 & 0.0346548 & 0.0282 \\
Feed costs, $10^{3} \mathrm{MX} \$ / \mathrm{cow} / \mathrm{d}$ & 2.53998 & 1.22447 & 0.0414 \\
Total assets per SSDF, $10^{6} \mathrm{MX} \$ / \mathrm{mon}$ & -0.133157 & 0.0718893 & 0.0678 \\
Holstein animals in SSDF, \% & -0.0015269 & 0.000889435 & 0.0901 \\
\hline
\end{tabular}

SEM = Standard error of the mean. 
productores los que están poniendo en riesgo su permanencia en la actividad lechera $(27,41)$. Este estudio muestra que una proporción del estrato de PUPL se acerca al potencial técnico de producción y establece una brecha de RE que habría que reducir imitando las estrategias de los más avanzados.

En el altiplano mexicano, la producción de leche de bovino se realiza bajo diferentes sistemas de producción; el sistema familiar considera que cada unidad económica funciona con el trabajo de una población ocupada formada por los integrantes de la familia y cuenta con acceso a pequeñas superficies de tierra, hatos menores a 60 bovinos y tecnificación rudimentaria o artesanal(15,40,41). También se han propuesto(42) otras clasificaciones para las PUPL como las que distinguen los grupos de subsistencia, especializado y mixto. En ningún caso es el parentesco entre el propietario y el personal ocupado lo que distingue el sistema de producción, sino las características técnicas y agroecológicas(26), lo cual sugiere que lo que distingue a las PUPL no es el tipo de personal ocupado (familiares -no familiares), sino otros factores como los señalados en el Cuadro 1.

El análisis de regresión lineal múltiple mostró que una $\mathrm{BCN}$ con superávit se relaciona directamente con la maximización de los ingresos obtenidos por la comercialización y el aprovechamiento en el uso de los recursos disponibles en las PUPL, así como las variables relacionadas con la minimización de los costos de producción (Cuadro 3). Se estimó que el modelo de regresión tiene una eficiencia del $88 \%$ para que una PUPL tenga valores superavitarios $(\mathrm{BCN}>1.0)$ mediante la tasa de concordancia de los valores observados y predichos. El modelo ajustado tuvo significancia $(P<0.001)$ y el estadístico $\mathrm{R}^{2}$ indicó que el modelo explicó el $82.8 \%$ de la variabilidad en $B C N$. Los coeficientes de regresión incluidos en el modelo fueron muy pequeños porque explicaban el impacto sobre la $\mathrm{BCN}$, la cual estuvo comprendida entre un rango de valores relativamente estrecho $(0.08$ y 1.83$)$. A between predicted and observed values. The adjusted model was significant $(P<0.001)$ and the $\mathrm{R}^{2}$-value showed that the model explained $82.8 \%$ of variability in NCB. The regression coefficients included in the model were very small because they explained the impact on $N C B$, which was contained within a relatively narrow value range ( 0.08 to 1.83$)$. Unlike the other coefficients, the proportion of Holstein cattle and the total value of SSDF assets had non-significant $(P>0.05)$ probability values, even in their exponential transformations, although they were very near the significance cut-off. However, these values were not excluded from the regression model because that would have affected the model's overall significance.

A large number of variables were excluded for two main reasons. Either they did not have significant $(P>0.05)$ influence on EP in the SSDF when analyzed together, or they exhibited a significant $(P<0.05)$ correlation with other model variables, suggesting colinearity between them(24). The key variables directly associated with EP were greater total income, value added generated, number of persons employed, number of family members paid wages, number of cows per employee, milk sale price and feed costs. These were indirectly related to lower total milk production operational costs, the percentage of milk production for family use, property value, cattle equipment and other assets. Other quantitative elements (e.g. growing sales, number of employees and herd size; improved productivity and efficiency) and qualitative elements (e.g. satisfaction of the client, employees and owner; capacity for innovation and company position) may also reflect competitive success in a dairy microbusiness(7).

Economic profitability and efficiency are not necessarily synonymous with competitiveness(3941). Indeed, efforts to remain in the dairy business have led some regions to change agricultural land use from dairy production to only forage production. For example, in the Aguascalientes Valley, most (95.4\%) agricultural 
diferencia de los demás coeficientes de regresión, la proporción de ganado de raza Holstein y el valor total de activos por PUPL tuvieron un valor de probabilidad no significativo $(P>0,05)$ aún en sus transformaciones exponenciales, aunque cercano a la significancia establecida, pero estas variables no fueron excluidas del modelo de regresión porque al hacerlo, se afectaba la significancia global del mismo.

En este estudio, una gran cantidad de variables fueron excluidas del modelo de regresión tanto porque no tuvieron influencia significativa $(P>0.05)$ en la RE de las PUPL al ser analizadas de manera conjunta o bien porque mostraban una correlación significativa $(P<0.05)$ con otras variables del modelo, y por lo tanto se consideró la existencia de una colinealidad entre ellas(24). Las variables clave que se asociaron directamente con la obtención de ganancias económicas fueron el incremento de ingresos totales obtenidos, valor agregado generado, cantidad de personas ocupadas, cantidad de familiares con salario, número de vacas atendidas por PO, precio de venta de leche y costo de alimentación; así como indirectamente con un menor monto total de egresos operativos erogados para la producción de leche, porcentaje de la producción destinada al autoconsumo familiar y el valor del predio, equipo ganado y otros activos. Además de estas variables clave, se ha sugerido(7) que otros elementos cuantitativos (ritmo creciente de las ventas, del número de empleados y del tamaño del hato; mejoramiento de la productividad y de la eficiencia) y cualitativos (satisfacción de los clientes, trabajadores y del propietario; capacidad de innovación y posición de la empresa) pudieran reflejar la existencia de éxito competitivo de las microempresas lecheras.

En el mismo sentido se ha mostrado(39-41) que RE y eficiencia no son sinónimo de competitividad; además, el esfuerzo por permanecer en la actividad lechera ha llevado a algunas regiones a cambiar el uso de la tierra agrícola, concentrándose solamente en la land has been changed over to forage (alfalfa, oats and corn) production(21). In other parts of the world, factors such as productivity per cow, milk sale price, feed costs and producer training have been reported as explaining economic results for $\operatorname{SSDF}(8,43)$.

Free trade agreements have pushed agricultural producers in Mexico directly into the international agricultural products market. This has tested the capacity of rural producers to compete with products from developed countries in local markets. Mexico has become one of the main importers of dairy products $(44,45)$, threatening to bankrupt many dairy products companies. The situation is especially precarious for small producers with limited technology, who have responded by overexploiting their natural resources (i.e. water sources, pastures, soil, biodiversity, and ecosystem resilience in response to climate change)(46). Import of dairy products at prices below local production costs also leads to loss of employment, a serious consequence given Mexico's abundant labor resources(47), and negatively affects the economic outlook of dairy production systems(42).

\section{CONCLUSIONS AND IMPLICATIONS}

The present results identified an economic profitability gap among small dairy production units in the Aguascalientes Valley. Only one out of every five dairy farms generated income greater than the whole value of labor, natural resources, inputs and technology used to generate the dairy products. Those SSDF that did attain or exceed the break-even point differed from unprofitable SSDF in their more efficient use of available resources. Productive factors that, together or individually, had a positive impact on EP were number of milking cows, number of cows worked per employee, feed unit costs, and the combination of inputs purchase and product sale in the market through an association or organization that aids in improving purchase/sale unit prices. These results suggest that national and local policy 
producción de los forrajes. Por ejemplo, en el valle de Aguascalientes se ha cambiado la actividad agropecuaria destinando la mayoría de los terrenos agrícolas (95.4\%) en áreas de producción de forrajes como alfalfa, avena y maíz(21). En otras regiones del mundo también se ha señalado $(8,43)$ que algunos factores como la productividad por vaca, el precio de venta de leche, el costo de alimentación y la capacitación a los productores, son relevantes para la explicación de los resultados económicos de las PUPL.

Los tratados de libre comercio han traído como consecuencia la incorporación del campo mexicano al comercio internacional agropecuario, así como también han puesto a prueba la capacidad de los campesinos nacionales para competir, al menos dentro del mercado local en contra de los países desarrollados. En este contexto, la leche de bovino ha sido uno de los productos agropecuarios en los que México se ha convertido el primer importador $(44,45)$, poniendo en riesgo de quebrar económicamente a las empresas lecheras, particularmente a aquellas que por su tamaño pequeño y por su escasa tecnología sólo han tenido la opción de llevar hasta extremos no sustentables el uso de sus recursos naturales, tales como sus fuentes de aprovisionamiento de agua, pastizales, suelos, biodiversidad y capacidad de resilencia del ecosistema ante el cambio climático(46). También se ha demostrado(47) que con la importación de productos lácteos a precios inferiores al costo de producción también se pierde el empleo de la mano de obra, que es un recurso abundante en México y se afecta la economía de los sistemas campesinos(42).

\section{CONCLUSIONES E IMPLICACIONES}

En este estudio se observó la existencia de una brecha de rentabilidad económica en las pequeñas unidades de producción lechera, pues sólo una de cada cinco obtuvo ingresos con un monto superior al valor conjunto de la mano de obra, recursos naturales, insumos y makers, as well as cattle association representatives, need to focus on bridging the economic profitability gaps among SSDF by improving production technical potential, refining commercial trade strategies, protecting employment and preserving natural resources.

\section{ACKNOWLEDGEMENTS}

The research was partially financed by the Universidad Autónoma de Aguascalientes (Project PIP/SA 08-5) and the Fondo Sectorial de Investigación en Materia Agrícola, Pecuaria, Acuacultura, Agrobiología y Recursos Fitogenéticos (SAGARPA-COFUPRO-CONACYT) Project No. 2010-144591.

End of english version

tecnología empleados en la generación de los productos lácteos. Las PUPL que alcanzaron el punto de equilibrio, difirieron de las deficitarias en el mejor aprovechamiento de los recursos disponibles; se identificaron factores productivos que de manera conjunta o individual tuvieron un impacto positivo en la RE como el número de vacas en ordeño, la producción de leche por vaca al día, el uso de la tecnología en el ordeño, el número de vacas atendidas por el personal ocupado, costos unitarios de alimentación y la concurrencia en el mercado de insumos y productos en conjunto de una asociación u organización que les permita mejorar los precios unitarios de compra venta. Estos resultados sugieren que es necesario recomendar a los tomadores de decisiones sobre políticas públicas nacionales y locales, así como a los representantes de las organizaciones ganaderas, que se encaminen esfuerzos hacia el cierre de brechas de rentabilidad económica entre pequeñas unidades lecheras, mejorando el alcance del potencial técnico de producción, las estrategias de intercambio comercial, la preservación del empleo y recursos naturales. 


\section{AGRADECIMIENTOS}

Se agradece el financiamiento parcial, obtenido de la Universidad Autónoma de Aguascalientes (Proyecto Clave PIP/SA 08-5) y del Fondo Sectorial de Investigación en Materia Agrícola, Pecuaria, Acuacultura, Agrobiología y Recursos Fitogenéticos (SAGARPA-COFUPRO-CONACYT), mediante la propuesta con clave 2010-144591,

\section{LITERATURA CITADA}

1. FAO-OECD. Sustainable agricultural productivity growth and bridging the gap for small-family farms. Interagency Report to the Mexican G20 Presidency. Paris, France: OECD publishing; 2012.

2. Tacken GML, Batowska A, Gardebroek C, Nesha-Turi K, Banse M, Wijnands JHM, Poppe KJ. Competitiveness of the EU dairy industry. Project code 20964, Report 2009-011. The Hague, The Netherlands: Agricultural Economics Research Institute (LEI) Wageningen UR; 2009.

3. FAO-FEPALE. Situación de la Lechería en América Latina y el Caribe en 2011, Observatorio de la Cadena Lechera. Santiago, Chile: Oficina Regional de la FAO para América Latina y el Caribe, División de Producción y Sanidad Animal; 2012.

4. Hanson JC, Johnson DM, Lichtenberg E, Minegishi K. Competitiveness of management-intensive grazing dairies in the mid-Atlantic region from 1995 to 2009. J Dairy Sci 2013;96(3):1894-1904.

5. INEGI. Censo Agrícola-Ganadero 1991. La ganadería familiar en México. Aguascalientes, México: INEGI; 1998.

6. INEGI. VIII Censo Agrícola, Ganadero y Forestal. Aguascalientes, México: INEGI; 2009.

7. Aragón A, Rubio A. Factores explicativos del éxito competitivo. El caso de las PyMEs del Estado de Veracruz. Rev Cont Adm 2005;216(2):35-69.

8. Alemdar T, Bahadir B, Necat-Oren M. Cost and return analysis and technical efficiency of small scale milk production: a case study for Cukurova región, Turkey. J Anim Vet Adv 2010;9(4):844-847.

9. Nahuelhual, L. A. Engler. Efecto del precio internacional sobre el precio de la leche pagado a productor: ¿transitorio o permanente? Agric Téc 2004;64(4):388-398.

10. Tauer LW, Mishra AK. Dairy farm cost efficiency. J Dairy Sci 2006;89(12):4937-4943.

11. Álvarez G, Herrera J, Barcena R, Martínez F, Hernández A, Pérez J. Calidad de la alimentación y rentabilidad de granjas lecheras familiares del sur del valle de México. Arch Zoot 2004;53(201):103-106.

12. Engler A, Nahuelhual L. Implications of the structural change in dairy products trade on milk price paid to producers in Chile. Chilean J Agric Res 2008;68(2):166-174.

13. Samuelson P, Nordhaus W. Economía. Madrid, España: Mc. Graw Hill; 1999.
14. García JG, Mariscal DV, Caldera NA, Ramírez H, Estrella R, Núñez R. Variables relacionadas con la producción de leche de ganado Holstein en agroempresas familiares con diferente nivel tecnológico. Interciencia 2007;32(12):841-846.

15. Carranza R, Macedo R, Cámara J, Sosa J, Meraz A, Valdivia AG. Competitiveness in the milk productive chain of Aguascalientes, México. Agrociencia 2007;41(6):701-709.

16. Latruffe L. Competitiveness, Productivity and Efficiency in the Agricultural and Agri-Food Sectors, OECD Food, Agriculture and Fisheries Working Papers, No. 30, Paris, France: OECD Publishing; 2010.

17. Porter ME. The competitive advantage of Nations. New York, USA: Free Press; 1990.

18. Castro CJ, Sánchez G, Iruegas LF, Saucedo G. Tendencias y oportunidades de desarrollo de la red leche en México. Boletín Informativo 317. 9a. Época. D.F. México: FIRA; 2001.

19. SAGARPA. Situación actual de la producción de leche de bovino en México 2005. México: SAGARPA; 2005. http:// www.campomexicano.gob.mx/portal_sispro/ index.php?portal=lechebovino, Consultada 25 jul, 2013.

20. SIAP. 2011. Boletín de leche de bovino. México: SAGARPA; 2013. http://www.siap.gob.mx/opt/estadistica/Derivada/ BoletinLeche/LecheMar2013.pdf. Consultada 25 jul, 2013.

21. INEGI. Perspectiva Estadística Aguascalientes. Aguascalientes, México: INEGI; 2011.

22. Segura J, Honhold N. Métodos de muestreo para la producción y la salud animal. Mérida, Yucatán, México: Universidad Autónoma de Yucatán; 2000.

23. Sánchez J, Rendón R, Cervantes-Escoto F, López Q. El agente de cambio en la adopción de innovaciones en agroempresas ovinas. Rev Mex Cienc Pecu 2013;4(3):305-318.

24. Johnson RA, Wichern DW. Applied Multivariate Statistical Analysis. 6th. Ed. Upper Saddle River, NJ, USA: Pearson, Prentice Hall; 2007.

25. Valdivia AG, Carranza RG, Gutiérrez JJ. La cadena productiva lechera en Aguascalientes. Su integración y competitividad. Serie Ciencias Biológicas, Agropecuarias y Medioambientales. Agroindustria. Aguascalientes, México: Procesos gráficos, UAA; 2007.

26. Espinosa JA, Wiggins S, González AT, Aguilar U. Sustentabilidad económica a nivel de empresa: aplicación a unidades familiares de producción de leche en México. Téc Pecu Méx 2004;42(1):55-70.

27. Álvarez A, del Corral J, Pérez JA, Solis D. Efecto de la intensificación sobre la eficiencia de las explotaciones lecheras. Econ Agr Recurs Nat 2007;7(13):91-106.

28. Álvarez A, del Corral J, Solis D, Pérez A. Does intensification improve the economic efficiency of dairy farms? J Dairy Sci 2008;91(9):3693-3698.

29. Aguilar A, López M. Cómo lograr que la ganadería lechera mexicana sea competitiva a nivel internacional. Rev Mex Agron 2006;18(1):1-14.

30. Tauer LW. Efficiency and competitiveness of the small New York dairy farm. J Dairy Sci 2001;84(11):2573-2576.

31. Lara D, Mora J, Martínez M, García G, Omaña J, Gallegos J. Competitividad y ventajas comparativas de los sistemas de producción de leche en el Estado de Jalisco. Agrociencia 2003;37(1):85-94.

32. Atria R, Siles M, Arriagada I, Robison LJ. Capital social y reducción de la pobreza en América Latine y el Caribe: en 


\section{BRECHAS DE RENTABILIDAD ECONÓMICA EN PEQUEÑAS UNIDADES LECHERAS}

busca de un nuevo paradigma. Santiago de Chile, Chile: Organización de las Naciones Unidas; 2003.

33. Cervantes F, Cesín A, Mamani I. 2013. La calidad estándar de la leche en el estado de Hidalgo, México. Rev Mex Cienc Pecu 2013;4(1):75-86.

34. Méndez MD, Tzintzun R, Val-Arreola D. Production evaluation, environmental effects and problems in small-scale dairy farms. Livest Res Rural Dev 2000;12(1): http://www.Irrd.org/ Irrd12/1/manu121.htm. Accesed Jul 24, 2013.

35. Bragg LA, Dalton TJ. Factors affecting the decision to exit dairy farming: a two-stage regression analysis. J Dairy Sci 2004;87(9):3092-3098.

36. Gale HF. Age-specific patterns of exit and entry in U.S. farming, 1978-1997. Rev Agric Econ 2003;25(1):168-186.

37. Pushkarskaya $H$, Vedenov D. Farming exit decision by age group: Analysis of tobacco buyout impact in Kentucky. J Agric Appl Econ 2009;41(3):653-662.

38. Cervantes $F$, Cesín A. La pequeña lechería rural o urbana en México, y su papel en el amortiguamiento de la pobreza. Rev Unell Cienc Tec 2007;(25):72-85.

39. Cervantes F, Cesín A, Pérez SL. El abandono de la ganadería lechera y reconversión productiva en Chipilo, Puebla. Téc Pecu Méx 2007;45(2):195-208.
40. Cervantes F, Santoyo H, Álvarez A. Lechería Familiar, factores de éxito para el negocio. México DF: Plaza y Valdés; 2001.

41. Cesín A, Aliphat M, Ramírez B, Herrera J, Martínez D. Ganadería lechera familiar y producción de queso, estudio en tres comunidades del municipio de Tetlatlahuca en el Estado de Tlaxcala, México. Téc Pecu Méx 2007;45(1):61-76.

42. Espinoza A, Álvarez A, Del Valle MC, Chauvete M. La economía de los sistemas campesinos de producción de leche en el Estado de México. Téc Pecu Méx 2005;43(1):39-56.

43. Engler A, Jahn E. Factores que afectan el margen de ingreso neto en lecherías: un análisis estadístico. Agric Téc (Chile) 2006;66(4):402-410.

44. OECD. Fostering Productivity and Competitiveness in Agriculture. Paris, France: OECD Publishing; 2011.

45. OECD. Agricultural Policy Monitoring and Evaluation 2011: OECD Countries and Emerging Economies. Paris, France: OECD Publishing; 2011.

46. Thornton PK, van de Steeg J, Notenbaert A, Herrero M. The impacts of climate change on livestock and livestock systems in developing countries: A review of what we know and what we need to know. Agric Syst 2009;101(3):113-127.

47. Ángeles R, Mora JS, Martínez MA, García R. Efecto de las importaciones de leche en el mercado nacional del producto. Agrociencia 2004;38(5):555-564. 
